
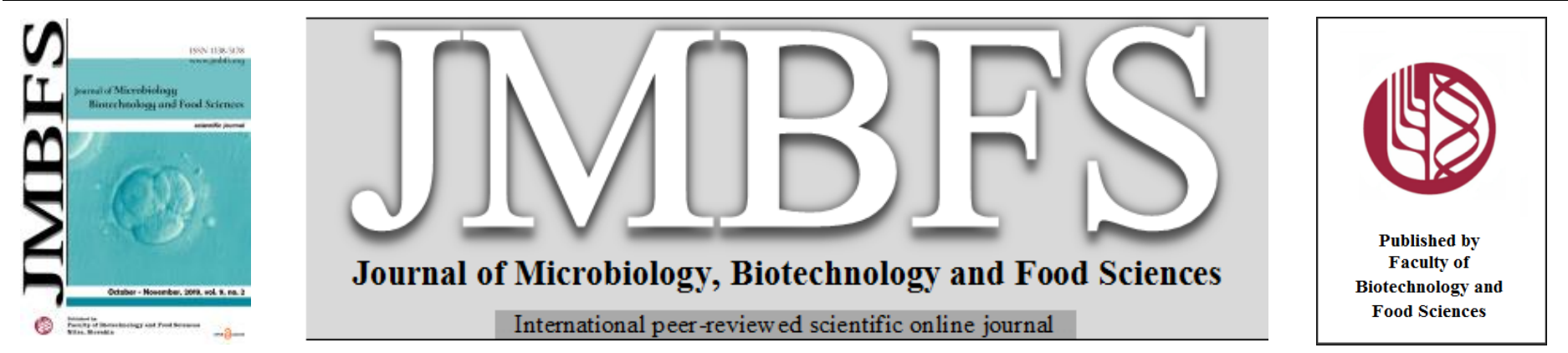

\title{
DEGRADATION KINETICS OF VITAMIN C AND $\beta$ - CAROTNE IN MANGO JUICE
}

Ogori A. $F^{* 1}$, Amove $J^{1}$, Ishaku S. $O^{2}$, Lukas Hleba ${ }^{3}$, Miroslava Císarová ${ }^{4}$, Petukhova Ekaterina ${ }^{5}$, Liudmila Sirotkina ${ }^{5}$, Anna Tsvelikhovskaya ${ }^{5}$, Ellina Bobruyko ${ }^{5}$, Aleksei Demidov ${ }^{5}$, Marina Kurazheva ${ }^{5}$, Mohammad Ali Shariati ${ }^{5,6}$

\author{
$\operatorname{Address(es):~}$ \\ ${ }^{1}$ Department of Food Science and Technology, Federal University of Agriculture, Makurdi, Benue State, Nigeria. \\ ${ }^{2}$ Department of Home Sciences, Faculty of Agriculture, Federal University, Gashua, P.M.B.1005 Gashua, Yobe State, Nigeria. \\ ${ }^{3}$ Department of Microbiology, Faculty of Biotechnology and Food Sciences, Slovak University of Agriculture in Nitra, Nitra, Slovak Republic. \\ ${ }^{4}$ University of SS. Cyril and Methodius, Department of Biology, Faculty of Natural Sciences, Nám. J. Herdu 2, SK-91701 Trnava, Slovak Republic. \\ ${ }^{5}$ K.G. Razumovsky Moscow State University of technologies and management (the First Cossack University), Moscow, Russian Federation. \\ ${ }^{6}$ Kazakh Research Institute of Processing and Food Industry (Semey Branch), Kazakhstan.
}

*Corresponding author: ogorifaraday@gmail.com, shariatymohammadali@gmail.com

doi: $10.15414 / j m b f s .2020 .9 .4 .861-864$

ARTICLE INFO

Received 15. 8. 2019

Revised 15. 10. 2019

Accepted 13. 11. 2019

Published 3. 2. 2020

Regular article

open $O$ ACcess

\begin{abstract}
Kinetics study on Vitamin C and beta-carotene degradation in mango juice was examined. Ten (10) mango fruits (Mangifera Indica) of the common cultivar were selected for analysis; the fruits were allowed to reach approximately $75 \%$ of full ripeness. Sixteen (16) samples of the mango juice were pasteurized at temperatures of $60^{\circ} \mathrm{C}, 70^{\circ} \mathrm{C}, 80^{\circ} \mathrm{C}$ and $90^{\circ} \mathrm{C}$ for $10,20,30,40$ minutes respectively, and kept under refrigerated conditions at $10^{\circ} \mathrm{C}$. The $\mathrm{pH}$ values at these periods ranged from 4.43-4.47. Results showed that both Vitamin $\mathrm{C}$ and beta carotene concentrations decreased with time following a zero order kinetic model. The highest $\mathrm{R}^{2}$ coefficient was 0.9955 in $\mathrm{Vitamin} \mathrm{C}$, while that of beta- carotene was 0.9872 . The Arrhenius plots (Ink versus $1 / \mathrm{T}$ ) showed the calculated activated energy $\mathrm{E}_{\mathrm{a}}=12.192 \mathrm{KJ} / \mathrm{mol}$ for Vitamin C. while the activation energy $E_{a}=19.097 \mathrm{KJ} / \mathrm{mol}$ for beta-carotene. Hereto, heat treatment of mango juice should be carried out under low temperature conditions at short given intervals to retain the vitamin $\mathrm{c}$ and beta-carotene contents after juicing, during processing.
\end{abstract}

Keywords: Degradation, Vitamin c, Beta-carotene, Kinetic

\section{INTRODUCTION}

Mango, often referred to as the king of tropical fruits, is an important fruit crop cultivated in tropical regions (Boghrma et al., 2000). The mango drupe- consisting of mesocarp (edible fleshy part) and endocarp (large woody, flatten pit). Apart from their importance in enhancing nutrition and food security, the mango fruits are increasingly being cultivated also for commercial purposes. Different cultivars of mango fruits are sold and consumed at different stages of maturity. These differences in cultivar, and post-harvest handling procedures may influence the carotenoid content in these fruits (Rodriguez-amaya, 2001). Mangoes, most probably contribute in alleviating vitamin A deficiency, whose prevalence is very high (Mwaniki et al., 2001). The vitamin content depends upon the variety and maturity of the fruit. When the mango is green, the amount of vitamin $\mathrm{C}$ is higher, as it ripens the amount of beta-carotene (vitamin A) increases. Mangoes are also rich in other non-provitamin A carotenoid. These have diverse roles and benefits for human health including antioxidant activity, cell communication, immune function enhancement and UV skin protection (Palozza and Krinsky, 1992) Vitamin $\mathrm{C}$ also known as ascorbic acid, functions as a water-soluble antioxidant and as a cofactor in various enzyme systems, such as those involved in the synthesis of connective tissue components and neurotransmitters. Beta-carotene is the pigment that gives mangoes their color. The human body can convert betacarotene into vitamin A, which is necessary for vision, immunity and skin health. Mangoes offer a good source of beta-carotene.

Food processing significantly lowers the quality of fruits and vegetables where in this study, mango fruit juice is concerned. Micronutrients are particularly affected, among them; beta-carotene and vitamin $\mathrm{C}$, temperature, occurrence of oxygen, the fruit composition and structure are known to affect vitamin $\mathrm{C}$ and beta-carotene loss significantly. However, the methods used to obtain kinetic parameters are of major importance in providing data to improve the outstanding and monitoring of vitamin $\mathrm{C}$ and beta-carotene retention during the processing mango juice and even at storage.

\section{MATERIAL AND METHODS}

\section{Materials}

Fresh Mango fruits (mangifera indica L.) were procured from Gboko market in Benue state. Green mature fruits were allowed $75 \%$ ripeness. The stages of maturity were determined using firmness, skin colour and total soluble solids (Vasqueze-Caicedo et al., 2003).

\section{Mango Juice Preparation}

Fresh mango fruits were washed, peeled and peeled into layers with a stainless steel knife. The slices were piled and blended with electric powered blender to get a homogeneous pulp. The final pulp volume was $1500 \mathrm{ml} .500 \mathrm{ml}$ of water was added to bring the mixture to a juice consistency. Residual pulps were removed by filtering to finally obtained clean juice using muslin clothe. The juice was poured into $100 \mathrm{ml}$ plastic container and pasteurized in a water bath at $60{ }^{\circ} \mathrm{C}, 70 \mathrm{C}, 80^{\circ} \mathrm{C}$ and $90^{\circ} \mathrm{C}$ for $10,20,30,40$ minutes respectively. After pasteurization, the product is allowed to cool and refrigerated at $10^{\circ} \mathrm{C}$.

\section{Methods}

\section{Vitamin C Determination}

The titration method described by AOAC (2004) was adopted. $10 \mathrm{ml}$ of distilled water was measured using pipette and transferred into a beaker. $5 \mathrm{ml}$ of juice sample was measured and diluted with distilled water contained in the beaker 2.5 $\mathrm{ml}$ of metaphophoric acid and make up to $50 \mathrm{ml}$ with distilled water. Using the pipette, $10 \mathrm{ml}$ of the mixture transferred into conical flask and $1 \mathrm{ml}$ of acetic acid added. The mixture was titrated against a prepared stansated solution of 2,6dichlorophenol indophenol DCPIP dye solution, until a distinct pink colour 
persisted for 5 minutes. The tire value was recorded and used as raw data to calculate the concentration of vitamin $\mathrm{C}$ in mango fruit juice.

$$
\text { Vitamin } C=\frac{\text { Dye concentration } X \text { titre value } \times 100}{\text { Volume of sample }}
$$

Where Dye concentration $=0.002 \mathrm{~g}$ and Volume of sample $=5 \mathrm{ml}$.

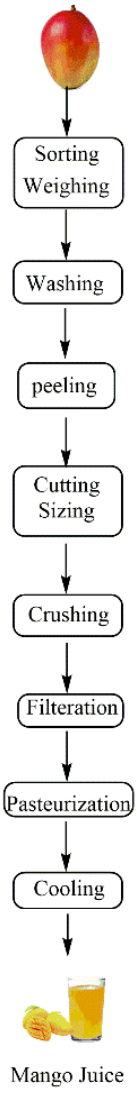

Figure 1 Mango juice extraction process

\section{$\beta$ - Carotene Determination pipette}

Beta -carotene concentration was extracted using hexaneas described by the method of Craft (2001). $5 \mathrm{mls}$ of the sample was measured into the conical flask using the pipette. $2 \mathrm{ml}$ of sodium chloride added to the sample. $10 \mathrm{mls}$ of methano and $20 \mathrm{mls}$ hexane were added respectively. Mixture shaken vigorously, using stirrer for 5 minutes and allowed to settle for about 20 minutes. Cleared colour solution was read for absorbency using spectrophotometer at $450 \mathrm{~nm}$ wave length.

$$
\text { Beta carotene }=\frac{\text { Absorbance }}{\text { Specific Extraction } \times \text { Path of cell coefficient2a }}
$$

Where Specific extraction confident $=$ wavelength $\mathrm{X}$ molar mass of beta carotene Path length $=1 \mathrm{~cm}$, and Molar mass of beta carotene $=536.88 \mathrm{~g}$

\section{Kinetic Data Analysis for vitamin C and Beta Carotene Degradation in pasteurized Mango Juice}

The methods of Ariahu and Ogunsua (2000)were adopted. The method used the concentration of vitamin $\mathrm{C}$ and Beta carotene versus time. This is used to ascertain vitamin concentration and beta carotene with time function at constant temperature.

The model $\mathrm{C}=\mathrm{Co}-\mathrm{Kt}$ which is Zero order kinetic, $\mathrm{C} / \mathrm{Co}=-\mathrm{Kt}$ which is First order kinetics and $\mathrm{C} / \mathrm{CO}=-\mathrm{KDt}$ which is Second order

Where

$\mathrm{C}=$ concentration of nutrient at time $\mathrm{t}$

$\mathrm{Co}=$ Initial concentration of nutrient at time zero

$\mathrm{K}=$ reaction rate constant
The kinetic model was fit into Shin et al. (2001) Equation to obtained a reaction rate. Through Arrhenius equation the regression analysis was related to absolute temperature in kelvin. Thus:

$\mathrm{K}=\mathrm{Ko}^{-\mathrm{Ea} / \mathrm{RT}}$

Where, $\mathrm{Ko}=$ Frequency pre-exponential factor, $\mathrm{Ea}=$ Activation energy.mol-1, $\mathrm{R}=$ Universal gas constant 8. 314J.K-1mol-1, T= Absolute temperature, Ea =From the slope of the graph, $\mathrm{Ko}=$ intercept of the graph

The decimal reduction time or $\mathrm{D}$-value were related to reaction rate constant by $\mathrm{D}=2.303 / \mathrm{K}$

\section{RESULTS AND DISCUSSION}

\section{pH Reading}

The $\mathrm{pH}$ readings obtained from the treated mango fruit juice are given in Table 1 . The $\mathrm{pH}$ values ranges from 4.43-4.71. Since $\mathrm{pH}$ has an influence on the stability of vitamin $\mathrm{C}$ in mango juice. Findings from FAO/WHO Expert consultation on human and mineral requirement reveals that the vitamin $\mathrm{C}$ will decay if the $\mathrm{pH}$ is higher than 4 (Bangkok-Thailand, 1998). This result also collaborated with that of Nagymate and Fodor, (2008).

Table $1 \mathrm{pH}$ of pasteurized mango juice at different temperatures and time.

\begin{tabular}{lcccc}
\hline & $\mathbf{6 0}^{\circ} \mathbf{C}$ & $\mathbf{7 0}^{\circ} \mathbf{C}$ & $\mathbf{8 0}^{\circ} \mathbf{C}$ & $\mathbf{9 0}^{\circ} \mathbf{C}$ \\
\hline $10 \mathrm{~min}$ & 4.43 & 4.57 & 4.61 & 4.71 \\
$20 \mathrm{~min}$ & 4.48 & 4.66 & 4.65 & 4.69 \\
$30 \mathrm{~min}$ & 4.51 & 4.61 & 4.66 & 4.68 \\
$40 \mathrm{~min}$ & 4.60 & 4.64 & 4.56 & 4.52 \\
\hline
\end{tabular}

Regression Analysis

Data obtained from vitamin $\mathrm{C}$ and beta-carotene degradation, were fitted into zero, first and second order reaction kinetics.

\section{Regression Analysis for the Degradation of vitamin C in Mango Juice}

The regression parameters are shown in Table 2. The first and the second order models gave low coefficient of the regression $\left(\mathrm{r}^{2}\right)$ between 0.5454 and 0.5368 respectively. The coefficient of regression $\left(r^{2}\right)$ is higher for the zero order models, which is 0.9955 . Figures $7-9$ show the relationship between concentration of vitamin $\mathrm{C}$ and heating time for mango juice.

Table 2 Reaction rate parameters for the degradation of vitamins $\mathrm{C}$ in pasteurized

\begin{tabular}{|c|c|c|c|c|c|}
\hline \multirow[b]{2}{*}{$\begin{array}{l}\text { Kinetics } \\
\text { Models }\end{array}$} & \multirow[b]{2}{*}{$\begin{array}{l}\text { Regression } \\
\text { Parameters }\end{array}$} & \multicolumn{4}{|c|}{ Concentration $^{\circ} \mathrm{C}$} \\
\hline & & 60 & 70 & 80 & 90 \\
\hline \multirow{3}{*}{$\begin{array}{c}\text { Zero order } \\
{\left[\mathrm{C}=\mathrm{C}_{0}-\mathrm{K}_{\mathrm{t}}\right]}\end{array}$} & $\mathrm{r}^{2}$ & 0.9955 & 0.931 & 0.9168 & 0.7426 \\
\hline & Intercept & 17.28 & 15.96 & 15.46 & 13.7 \\
\hline & Gradient & 0.199 & 0.215 & 0.277 & 0.289 \\
\hline \multirow{3}{*}{$\begin{array}{l}\text { First order } \\
\operatorname{Ln}\left(C / C_{0}\right)=-K_{t}\end{array}$} & $r^{2}$ & 0.5322 & 0.5294 & 0.5454 & 0.5384 \\
\hline & Intercept & 10.772 & 10.688 & 10.676 & 10.5 \\
\hline & Gradient & 0.2788 & 0.2817 & 0.2916 & 0.297 \\
\hline \multirow[t]{3}{*}{$\begin{array}{l}\text { Second order } \\
\mathrm{C} / \mathrm{C}_{0}=-\mathrm{KDT}\end{array}$} & $r^{2}$ & 0.528 & 0.527 & 0.5368 & 0.5179 \\
\hline & Intercept & 9.964 & 9.908 & 9.848 & 9.502 \\
\hline & Gradient & 0.2769 & 0.2793 & 0.2881 & 0.2953 \\
\hline
\end{tabular}
mango juice

\section{Degradation of vitamin $\mathrm{C}$ in mango juice}

Table 3 depicts the reaction rate, $\mathrm{D}$-value and activation energy evaluated. The $\mathrm{D}$ value was highest in zero order11.57 and lowest in the first order 7.89. The second order had a D-value of 7,99 respectively. For the gradient K, the value was higher for the first order 0.2916 , this was followed by the second order 0.288 and lowest for the zero order 0.199 .

Table 3 Reaction rate K, D -value and Ea for Vitamin C degradation in mango juice

\begin{tabular}{cccc}
\multirow{3}{*}{ Parameter } & \multicolumn{3}{c}{ Kinetic models } \\
\cline { 2 - 4 } & Zero order & first order & Second Order \\
\cline { 2 - 4 } K & $\mathrm{C}=\mathrm{C} 0-\mathrm{Kt}$ & {$[\operatorname{In}(\mathrm{C} / \mathrm{Co})=-\mathrm{kt}]$} & {$[\mathrm{C} / \mathrm{C} 0=-\mathrm{kDT}]$} \\
D-value & 0,199 & 0.2916 & 0.2881 \\
& 11.573 & 7.898 & 7.994 \\
\hline
\end{tabular}

Activation Energy 12.192, Key: K =gradient, D -values=decimal reduction 
Figures 2-4 depicts the kinetic Vitamin C concentration versus time considering different kinetic models.

Time

(minutes)

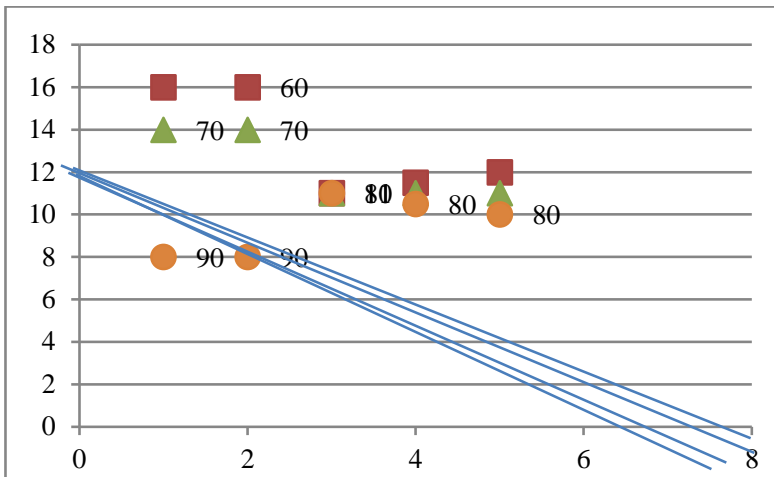

Figure 2 Graph of vitamin $\mathrm{C}$ concentration versus Time. Zero order $(\mathrm{C}=\mathrm{C} 0-\mathrm{Kt})$, Series $1=60{ }^{\circ} \mathrm{C}$, Series $2=70{ }^{\circ} \mathrm{C}$, Series $3=80{ }^{\circ} \mathrm{C}$, Series $4=90{ }^{\circ} \mathrm{C}$. Y-axis (Concentration of vitamin $\mathrm{C} \mathrm{mg} / \mathrm{ml}$ )

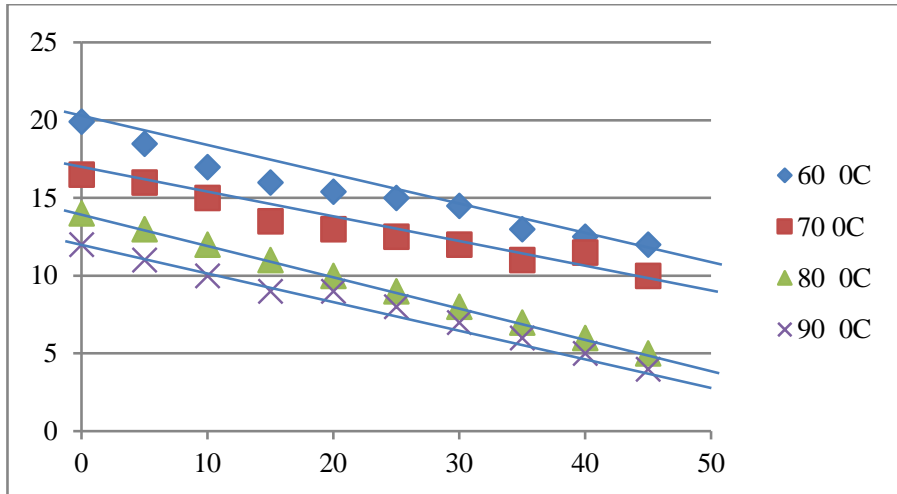

Time (min)

Figure $3 \mathrm{Graph}$ of vitamin $\mathrm{C}$ concentration versus Time. First order $(\mathrm{C} / \mathrm{C} 0=-\mathrm{Kt})$, Series $1=60{ }^{\circ} \mathrm{C}$, Series $2=70{ }^{\circ} \mathrm{C}$, Series $3=80{ }^{\circ} \mathrm{C}$, Series $4=90{ }^{\circ} \mathrm{C}$, Y-axis (Concentration of vitamin $\mathrm{C} \mathrm{mg} / \mathrm{ml}$ )

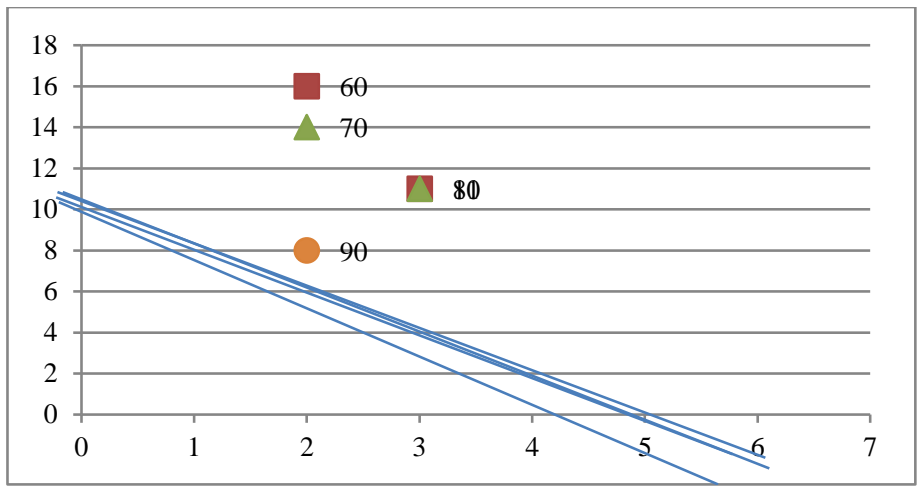

Time (min)

Figure 4 Graph of vitamin $\mathrm{C}$ concentration versus Time. Second order $(\mathrm{C} / \mathrm{Co}=-$ $\mathrm{KDt}$ ), Series $1=60{ }^{\circ} \mathrm{C}$, Series $2=70{ }^{\circ} \mathrm{C}$, Series $3=80{ }^{\circ} \mathrm{C}$, Series $4=90{ }^{\circ} \mathrm{C}$, Y- axis (Change in concentration of vitamin $\mathrm{C} \mathrm{mg} / \mathrm{ml}$ )

\section{Regression Analysis for the degradation of Beta-carotene in mango juice.}

The regression parameters are shown in Table 3. The first and second order models gave a low coefficient of regression $\left(r^{2}\right)$ between 0.9974 and 0.9941 respectively. The coefficient of regression $\left(\mathrm{r}^{2}\right)$ is higher for the zero order models, which is 0.9976 figures 10-12 show the relationship between concentration of beta-carotene and heating time for the mango juice.

\section{Kinetic degradation of Beta carotene in Mango juice.}

Table 4 depicts the reaction rate. The $\mathrm{D}$-value was highest in the second order76.76 and lowest in the zero order 20.38. The first order had a D-value of 46.06 respectively. For the gradient K, the value was higher for the second order 23.1, this was followed by the first order 13.86 and lowest for the zero order 6.13
Table 3 Reaction rate parameters for the degradation of $\beta$-carotene in pasteurized mango juice

\begin{tabular}{llcccc}
\hline & & \multicolumn{4}{c}{ Concentration $^{\circ} \mathbf{C}$} \\
\cline { 4 - 6 } Kinetics Models & $\begin{array}{l}\text { Regression } \\
\text { Parameters }\end{array}$ & 60 & 70 & 80 & 90 \\
\hline Zero order & $\mathrm{r}^{2}$ & 0.9872 & 0.9839 & 0.9976 & 0.8586 \\
{$\left[\mathrm{C}=\mathrm{C}_{0}-\mathrm{K}_{\mathrm{t}}\right]$} & Intercept & 2.655 & 2.07 & 1.6 & 1.6 \\
& Gradient & 0.0113 & 0.0053 & 0.0082 & 0.0107 \\
& & & & & \\
First order & $\mathrm{r}^{2}$ & 0.9839 & 0.9809 & 0.9974 & 0.8416 \\
Ln $\left(\mathrm{C} / \mathrm{C}_{0}\right)=-\mathrm{K}_{\mathrm{t}}$ & Intercept & 0.982 & 0.7295 & 0.627 & 0.491 \\
& Gradient & 0.0048 & 0.0028 & 0.005 & 0.0084 \\
& & & & & \\
Second order & $\mathrm{r}^{2}$ & 0.978 & 0.975 & 0.9941 & 0.8211 \\
$\mathrm{C} / \mathrm{C}_{0}=-\mathrm{KDT}$ & Intercept & 0.3725 & 0.4815 & 0.531 & 0.5945 \\
& Gradient & 0.002 & 0.0014 & 0.003 & 0.0065 \\
\hline
\end{tabular}

Table 4 Reaction rate K, D -value and Ea for Vitamin C degradation in mango juice

\begin{tabular}{lccc}
\hline \multirow{3}{*}{ Parameter } & \multicolumn{3}{c}{ Kinetic models } \\
\cline { 2 - 4 } & Zero order & first order & Second Order \\
\cline { 2 - 4 } K & $\mathrm{C}=\mathrm{C} 0-\mathrm{Kt}$ & {$[\mathrm{In}(\mathrm{C} / \mathrm{Co})=-\mathrm{kt}]$} & {$[\mathrm{C} / \mathrm{C} 0=-\mathrm{kDT}]$} \\
$\mathrm{D}$-value & 0.0113 & 0.005 & 0.003 \\
\hline A & 20.38 & 46.06 & 76.76 \\
\hline
\end{tabular}

Activation Energy $19.9099 \mathrm{KJ} / \mathrm{mol}$, Key: K =gradient, D -values=decimal reduction

Figures 5-7 depicts the kinetic Beta-carotene concentration versus time considering different kinetic models.

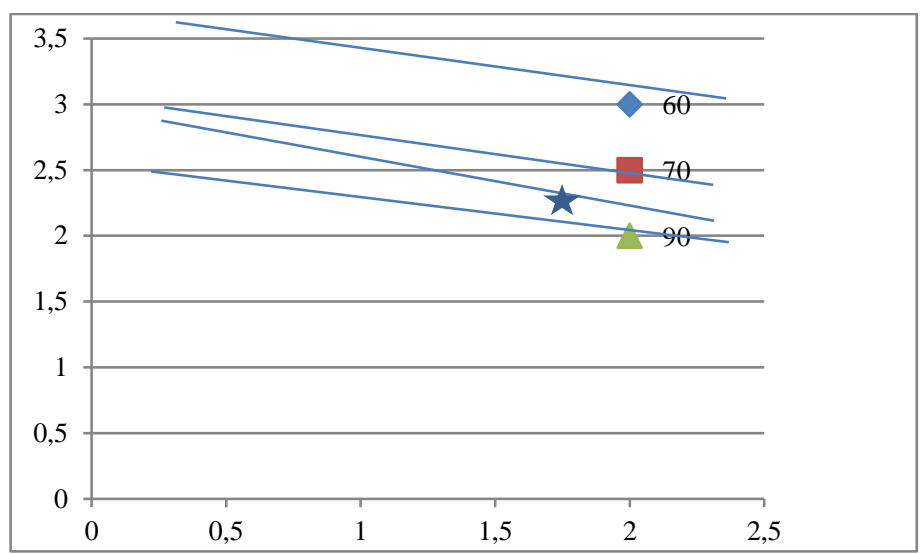

Time (min)

Figure 5 Graph of beta- carotene concentration against Time. zero order (C $\mathrm{C} 0=\mathrm{Kt}$ ), Series $1=60^{\circ} \mathrm{C}$, Series $2=70^{\circ} \mathrm{C}$, Series $3={ }^{\circ} 80^{\circ} \mathrm{C}$, Series $4=90^{\circ} \mathrm{C}$, yaxis ( $\beta$-carotene Concentration in $\mathrm{mol} / \mathrm{ml}$ )

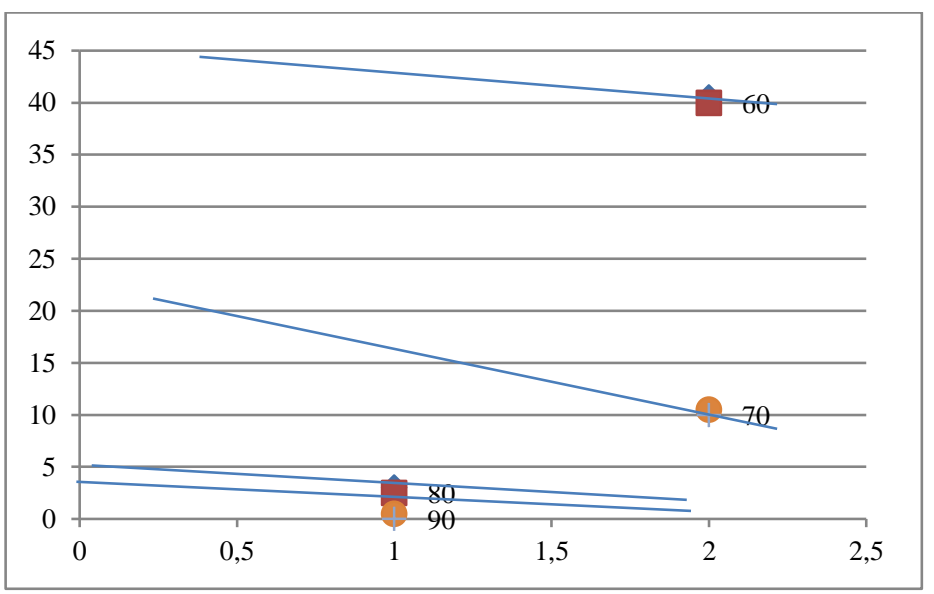

Time (min)

Figure $6 \mathrm{Graph}$ of beta- carotene concentration against Time. First order [ $\mathrm{In}(\mathrm{C} / \mathrm{C} 0)$

$=-\mathrm{Kt}$ ], Series $1=60^{\circ} \mathrm{C}$, Series $2=70^{\circ} \mathrm{C}$, Series $3=80^{\circ} \mathrm{C}$, Series $4=90{ }^{\circ} \mathrm{C}$, y-axis ( $\beta$-carotene Concentration in $\mathrm{mol} / \mathrm{ml}$ ) 


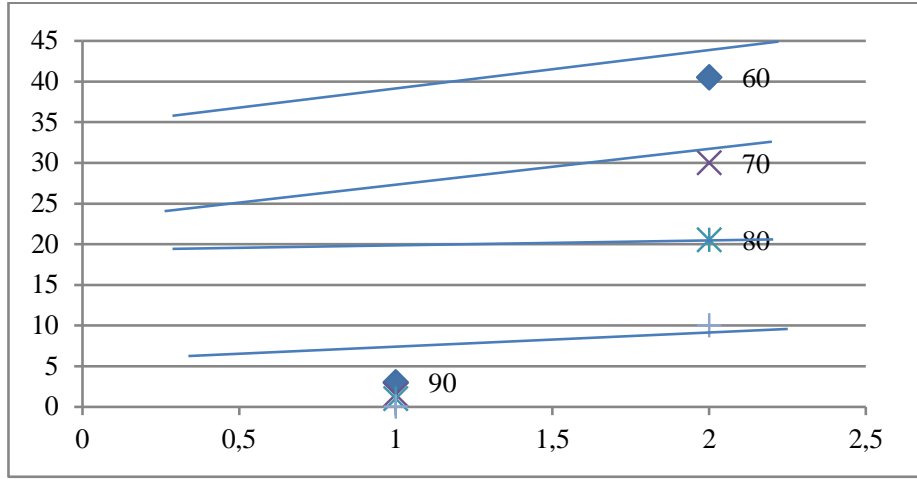

Time (Min)

Figure 7 Graph of beta- carotene concentration against Time. Second order in [C $/ \mathrm{C} 0=-\mathrm{KDt}$, Series $1=60^{\circ} \mathrm{C}$, Series $2=70^{\circ} \mathrm{C}$, Series $3=80^{\circ} \mathrm{C}$, Series $4=90{ }^{\circ} \mathrm{C}$, yaxis ( $\beta$-carotene Concentration in $\mathrm{mol} / \mathrm{ml}$ )

\section{Calculation of activation energy $\left(\mathbf{E}_{\mathrm{a}}\right)$}

Activation energy $\left(\mathrm{E}_{\mathrm{a}}\right)$ was estimate $\mathrm{d}$ from the reaction rate constant $(\mathrm{K})$ and multiplied by the universal gas constant $(\mathrm{R}=8.314 \mathrm{KJ} / \mathrm{mol})$. Arthenius plot (Ink vs $1 / \mathrm{T}$ ) for vitamin $\mathrm{C}$ and beta-carotene degradation in mango juice is given in Figure 8 and 9 respectively.

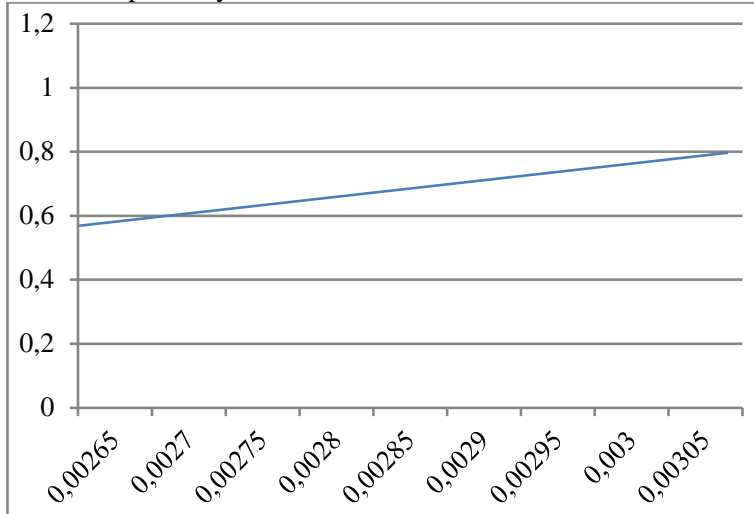

Figure 8 Arrehenuis plot equation lnk versus1/T FOR Degradation of vitamin C in pasteurised mango juice, $\mathrm{y}=-1466.4 \mathrm{x}+5.974, \mathrm{R}^{2}=0.9653, \mathrm{Ea}=12.192 \mathrm{kj} / \mathrm{mol}$.

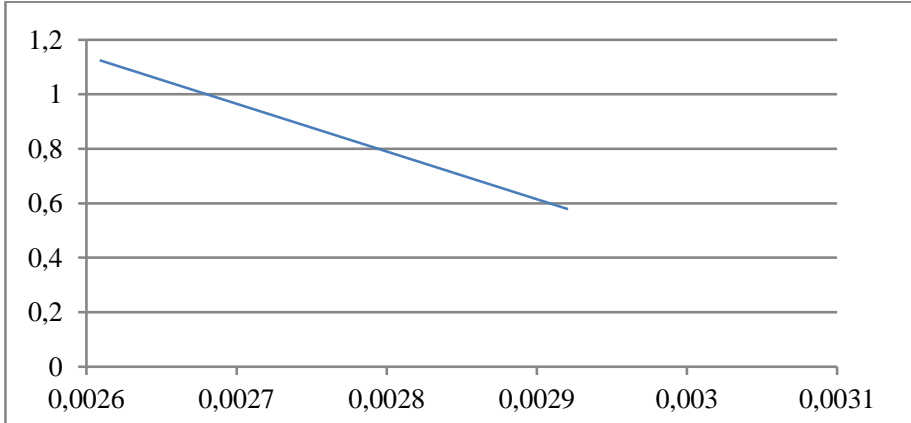

Figure 9 Arrehenuis plot equation lnk versus1/T for Degradation of beta carotene in pasteurised mango juice, $y=-1466.4 x+5.974, R^{2}=0.9653, E a=12.192 \mathrm{kj} / \mathrm{mol}$

\section{CONCLUSION}

Kinetics of vitamin $\mathrm{C}$ and beta-carotene degradation in mango fruit juice were evaluated. Results showed that the concentration of vitamin $\mathrm{C}$ and beta-carotene were affected by storage temperature and processing time, vitamin $\mathrm{C}$ and betacarotene degrade faster at higher temperature and longer processing time. Results show that the highest coefficient of regression $\left(\mathrm{r}^{2}\right)$ is 0.9955 for vitamin $\mathrm{C}$ degradation and 0.9872 for beta-carotene degradation respectively. The activation energy $\left(E_{a}\right)$ for vitamin $C$ in the pasteurized mango juice is calculated to be 12.192 $\mathrm{KJ} / \mathrm{mol}$, while that of beta-carotene is $19.097 \mathrm{KJ} / \mathrm{mol}$.

\section{REFERENCES}

AOCS. (2004). Official methods of analysis of analysis of the association of analytical chemist international 18 edi gatherburg MD USA official methods. Araihu, C.C., \& Ogunsua A.O. (2000) Thermal degradation kinetics of thiamine in periwinkle based formulated low acidity food. International Journal of Food
Science and Technology, 35,315-321. https://doi.org/10.1046/j.13652621.2000.00366.x

Bangkok-Thailand. (1998). WHO Library Cataloguing-in-Publication DataJoint FAO/WHO Expert Consultation on Human Vitamin and Mineral Requirements (1998: Bangkok, Thailand). Vitamin and mineral requirements in human nutrition: report of a joint FAO/WHO expert consultation, Bangkok, Thailand, 21-30 September 1998.1. Vitamins standards2.Micronutrients standards3.Trace elements standards.

Boghrma, V., Sharma, R. S., \& Puravankara, D. (2000). Effect of antioxidant principles isolated from mango (Mangifera indicaL) seed kernels on oxidative stability of buffalo ghee (butter fat). Journal of the science of Food and Agriculture, $\quad 80, \quad 522-526 . \quad$ https://doi.org/10.1002/(sici)10970010(200003)80:4<522::aid-jsfa560>3.0.co;2-r.

Craft, N. (2001). Chromatography techniques for caroteneseparation current protocols in food analytical chemistry PF2.3.1-F2.315.

Mwaniki, M.K., Gatakaa, H.W., Mturi, F.N., Chesaro, C.R., Chuma, J.M., \& Peshu, N. M. (2001) An increase in the burden of neonatal admissions to a rural district hospital in Kenya over 19 years. BMC PublicHealth,10, 591. https://doi.org/10.1186/1471-2458-10-591.

Nagymate, E. \& Fodor, P. (2008). The stability of vitamin C in different beverages. British Food Journal, 110(3), 296-309. https://doi.org/10.1108/00070700810858709.

Palozza, P., \&Krinsky, N.I. (1992). Antioxidant effects of carotenoids in vivo and in vitro: an overview. Methods of Enzymology, 213, 403-420 https://doi.org/10.1016/0076-6879(92)13142-k .

Rodriguez-Amaya, D.B. (2001). A guide to Carotenoid Analysis in Foods. ILSI Press, Washington DC, USA.

Shin, J.H., Chung, H.I., So, J.K., Sim, J.h., Huh, C.S., Kil, S.K., \& Baek, Y. J. (2001) Degradation ketitics of capsanthin in parika (Capsanthin annum L.) as affected by heating. Journal of Food Science, 66, 1518. https://doi.org/10.1111/j.1365-2621.2001.tb15575.x.

Vásquez-Caicedo, A. L. Schilling, S., Carle, R., \& Neidhart, S. (2007). Effects of thermal processing and fruit matrix on $\beta$-carotene stability and enzyme inactivation during transformation of mangoes into purée and nectar. Journal of Food Chemistry, 102 (4), 1172-1186. https://doi.org/10.1016/j.foodchem.2006.07.005. 